\title{
PENGARUH FASILITAS KANTOR DAN KEDISIPLINAN KERJA TERHADAP KINERJA PEGAWAI DINAS KETENAGAKERJAAN KOTA MEDAN
}

Oleh:

\author{
Jonner Lumban Gaol ${ }^{1)}$ \\ Lamminar Hutabarat ${ }^{2)}$ \\ Endieni Meisari Bate'e ${ }^{3)}$ \\ Universitas Darma Agung, Medan 1,2,3) \\ E-mail: \\ jonnerlumbangaol120@gmail.com ${ }^{1)}{ }_{\text {hutabaratmin23@gmail.com }}{ }^{2)}$ \\ endienimeisari@gmail.com ${ }^{3)}$
}

\begin{abstract}
The purposes of this research is to know the significant influence between office office facilitiesrhe performance of the city employment worker medan this research hypothesis is that there is a significant influence between office facilities and occupational discipline on the performance of the field service employee. The research is done on the employment service of Medan city. On this study the object of research is restricted to the variable office facilities and the discipline of work as free and performance variables as constrained variables. The method of gathering data used is literature studies and field studies with a quantitative approach. The research data was obtained by laying out questionnaire to 30 people. Later the data is prepared by multiple linear regression using SPSS 22. Based on data, office facilities and office discipline on the performance of the labor-town employment officer Medan. Based on the linear regression calculations with the formula: $Y=a+b 1 X 1+b 2 X 2$ adalah $Y=8,501+0,986 X_{1}+$ $0,194 X_{2}$. The conclusion reached in this study is: an individual or a partial test (test $t$ ) shows variable office facilities having a positive effect on the employee's performance ( $t$ count 7,291 > t table 2,0518) while word-enforcement variables $(t$ count 1,039<t table 2,0518) meaning to have no positive and significant influence on the performance of employment service workers. Based on the result of $f$ levels of 32,097 > 3,35 means simultaneous effect of office facilities and occupational discipline on the performance of thr field service workers. The value of adjusted $R$ square 0,981 adjusts the impact of office facilities and wok discipline by $68,2 \%$ while the rest are being effected by other variables.
\end{abstract}

Keyword: office facilities, employee work and performance discipline. 


\begin{abstract}
ABSTRAK
Tujuan penelitian ini adalah untuk mengetahui pegaruh signifikan antara fasilitas kantor kedisiplinan kerja terhadap kinerja pegawai Dinas Ketenagakerjaan Kota Medan. Hipotesis penelitian ini adalah terdapat pengaruh yang signifikan antara fasilitas kantor dan kedisiplinan kerja terhadap kinerja pegawai Dinas Ketenagakerjaan Kota Medan.Penelitian ini dilakukan pada Dinas Ketenagakerjaaan Kota Medan. Pada penelitian ini objek penelitian dibatasi hanya terdapat variabel Fasilitas Kantor dan Kedisiplinan Kerja sebagai variabel bebas dan Kinerja variabel terikat. Metode pengumpulan data yang digunakan dalah studi kepustakaan dan studi lapangan dengan pendekatan kuantitatif. Datadata dalam penelitian diperoleh dengan menyebarkan kuesioner kepada 30 (tiga puluh) orang responden. Selanjutnya data diolah dengan regresi linier berganda dengan menggunakan alat bantu SPSS 22. Berdasarkan hasil data pengolahan data tersebut, fasilitas kantor dan kedisiplinan kerja berpengaruh terhadap kinerja pada pegawai. Adapun pengaruh fasilitas kantor dan kedisiplinan kerja terhadap kinerja pegawai Dinas Ketenagakerjaaan Kota Medan. berdasarkan perhitungan regresi linier berganda dengan rumus: $\mathrm{Y}=\mathrm{a}+\mathrm{b} 1 \mathrm{X} 1+\mathrm{b} 2 \mathrm{X} 2+$ adalah $\mathrm{Y}=8,501+$ $0,986 \mathrm{X}_{1}+0,194 \mathrm{X}_{2}$ Kesimpulan yang didapat dalam penelitian Ini adalah: hasil uji secara individual atau secara parsial (Uji t) menunjukan variabel fasilitas kantor mempunyai pengaruh positif terhadap kinerja pegawai ( $t_{\text {hiting }} 7,291>t_{\text {tabel }} 2,0518$ ) sedangkan variabel kedisiplinan kerja ( $\left.t_{\text {hitung }} 1,039<2,0518\right)$ artinya tidak memiliki pengaruh positif dan signifikansi terhadap kinerja pegawai Dinas

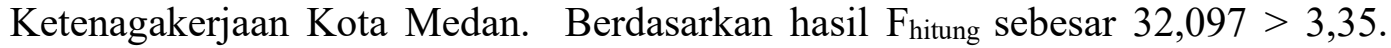
Berarti ada pengaruh fasilitas kantor dan kedisiplinan kerja secara simultan (bersamaan) terhadap kinerja pegawai Dinas Ketenagakerjaan Kota Medan. Nilai adjusted R Square 0,682 menggambarkan pengaruh fasilitas kantor kedisiplinan kerja sebesar $68,2 \%$ sedangkan sisa dipengaruhi oleh variabel lain.
\end{abstract}

Kata kunci: fasilitas kantor, kedisiplinan kerja, kinerja pegawai.

\section{PENDAHULUAN}

Dinas Ketenagakerjaan adalah suatu lembaga Pemerintahan yang melakukan pelayanan terhadap tenaga kerja dalam rangka mempersiapakan tenaga kerja yang siap pakai sebagai hasil kerja sama dengan-lembaga pelatihan yang ada. Dinas tenaga kerja juga turut serta dalam memperjuangkan hak-hak orang-orang untuk memperoleh pekerjaan yang layak dengan memberiakan pelayanan serta persiapan untuk masuk dunia kerja. Oleh karena itu demi mewujudkan hal tersebut diperlukan fasilitas yang mendukung para pegawai agar aktivitas berjalan sesuai tujuan yang ingin dicapai. Seorang pegawai harus dapat mengoperasikan atau memanfaatkan fasilitas yang ada. Fasilitas adalah segala sesuatu yang digunakan, dipakai, ditempati, oleh pegawai baik dalam hubungan lingkungan dengan pekerjaan maupun untuk kelancaran pekerjaan, dalam hal ini menurut 
pelaksanaannya perlu melakukan suatu penilaian kinerja pegawai.

Kinerja merupakan jawaban dari berhasil tidaknya tujuan organisasi. Kinerja pegawai diketahui dari seberapa jauh pegawai melaksanakan tugas sesuai tanggung jawabnya. Kinerja adalah hasil kerja secara kualitas dan kuantitas yang dicapai oleh seseorang pegawai dalam melaksanakan tugasnya sesuai dengan tanggungjawab yang diberikan kepadanya. Hasil kinerja yang baik salah satunya apabila pegawai mampu memberikan pelayanan yang baik kepada masyarakat.Kedisiplinan merupakan fungsi operatif manajemen sumber daya manusia yang terpenting karena semakin baik disiplin karyawan, semakin tinggi prestasi kerja yang dapat dicapainya. Tanpa disiplin yang baik, sulit bagi organisasi mencapai hasil yang optimal. Kedisiplinan adalah kesadaran dan kesediaan seseorang mentarhadaati semua peraturan perusahaan dan norma-norma sosial yang berlaku. Kesadaran adalah sikap seseorang yang secara suka rela menaati semua peraturan dan sadar akan tugas dan tanggung jawabnya. Dalam penelitian ini penulis membatasi permasalahan pembahasan berfokus pada fasilitas kantor, kedisiplinan kerja dan kinerja para pegawai Dinas Ketenagakerjaan Kota Medan.

\section{Manfaat Penelitian}

Bagi Penelitian

Penelitian ini diharapkan dapat memberikan kontribusi dalam rangka memberikan pengetahuan atau pengalaman bagi para peneliti di Universitas Darma Agung dalam melakukan penelitian baik secara teori maupun praktik serta menerapkan dan mengembangkan ilmu pengetahuan yang diperoleh.

Bagi Pembaca

Penelitian diharapkan dapat menjadi sumber bacaan yang bermanfaat sebagai referensi atau bahan pustaka bagi para peneliti di Universitas Darma Agung maupun kalangan pegawai dalam suatu instansi terutama Dinas Ketenagakerjaan Kota Medan .

\section{Manfaat Praktis}

Penelitian ini diharapkan dapat menjadi pedoman atau masukan bagi kalangan pegawai dalam suatu instansi terutama di Dinas Ketenagakerjaan Kota Medan akan pentingnya pemanfaatan fasilitas kantor dan kedisiplinan kerja dalam hal kinerja pegawai. Kinerja pegawai dilihat dari kepatuhan dalam mengikuti aturan dalam suatu instansi dimana orang tersebut bekerja sehingga kedisiplinan dalam melaksanakan pekerjaan akan terlihat dari perilakunya. Sibagariang $\mathrm{O}$, Manalu T \& Girsang W (2019), Gunawan S, Tanuwijaya N, Paulus O \& Linda L (2019), Desani A, Tangelica M \& Irisa W (2019).

\section{TINJAUN PUSTAKA \\ Pengertian Fasilitas Kantor}

Fasilitas merupakan segala hal yang dapat memudahkan dan melancarkan pelaksanaan kegiatan, yang dapat memudahkan kegiatan dapat berupa sarana dan prasarana. "Fasilitas adalah sarana melancarkan pelaksanaan fungsi" (Lupiyoadi, 2009:389). Berdasarkan pengertian di atas dapat disimpulkan bahwa fasilitas kerja adalah segala sesuatu yang berupa sarana atau alat yang 
digunakan untuk mempermudah aktivitas kantor sehingga pegawai Dinas Ketenagakerjaan Kota Medan dapat melaksanakan pekerjaannya dengan baik.

Indikator Fasilitas

Menurut Faisal (2005:22) indikator yang digunakan untuk mengukur fasilitas, yaitu:

1. Komputer, Meja Kantor

2. Parkiran

3. Bangunan kantor

4. Transportasi.

\section{Pengertian Kedisiplinan}

Kedisiplinan merupakan sikap yang diperlukan untuk mendapat perhatian dalam usaha meningkatkan kinerja.

"Kedisiplin adalah kemampuan kerja seseorang untuk secara teratur, tekun terus menerus dan bekerja sesuai dengan aturan-aturan berlaku dengan tidak melanggar aturan-aturan yang sudah ditetapkan" (Sinambela, 2012:239).

Perlu ditambahkan bahwa "disiplin merupakan sikap dan perilaku kepatuhan terhadap peraturan organisasi, prosedur kerja, kode etik, dan norma budaya organisasi lainnya yang harus dipatuhi dalam memproduksi suatu produk dan melayani konsumen organisasi" (Wirawan, 2009:138).

Ditinjau dari pendapat para ahli tersebut dapat disimpulkan bahwa disiplin adalah usaha untuk menanamkan nilai dalam menciptakan suatu sikap patuh pada aturan-aturan kerja tertentu dan bertanggung jawab pada pekerjaannya.

\section{Tujuan Pendisiplinan}

Pendisiplinan merupakan tindakan organisasi yang tidak mengakibatkan seorang pegawai kehilangan sesuatu dari organisasi" (Wirawan, 2009:138). Pendisiplinan bersifat konstruktif atau memperbaiki karena pendisiplinan merupakan bagian dari proses pembelajaran. Berikut ini tujuan pendisiplinan, antara lain:

1. Memotivasi karyawan untuk mematuhi standar kinerja perusahaan. Seorang karyawan mendapatkan pendisiplinan dari organisasi setelah gagal memenuhi kewajibannya.

2. Mempertahankan hubungan saling menghormati antara bawahan terhadap atasan atau sebaliknya.

3. Meningkatkan kinerja karyawan. Pendisiplinan wajib dilakukan bagi karyawan berkinerja rendah yang bukan disebabkan oleh faktor non manusia.

4. Meningkatkan moril, semangat kerja, etos kerja, serta efektifitas, dan efisiensi kerja. Meningkatkan moril, semangat kerja, etos kerja, serta efektifitas, dan efisiensi kerja pegawai menurun karena pengaruh keadaan lingkungan eksternal organisasi.

5. Meningkatkan kedamaian industri dan kewargaan organisasi pegawai hanya dapat bekerja dengan baik jika bekerja dalam iklim kedamaian, kerja sama, dan saling menghormati.

\section{Indikator Disiplin}

Veithzal Rivai (2010:825) menjelaskan bahwa, disiplin kerja memiliki beberapa komponen seperti:

1. Kehadiran. Hal ini menjadi indikator yang mendasar untuk mengukur kedisiplinan, dan biasanya karyawan yang memiliki 
disiplin kerja rendah terbiasa untuk terlambat dalam bekerja.

2. Ketaatan pada peraturan kerja. Karyawan yang taat pada peraturan kerja tidak akan melalaikan prosedur kerja dan akan selalu mengikuti pedoman kerja yang ditetapkan oleh perusahaan.

3. Ketaatan pada standar kerja. Hal ini dapat dilihat melalui besarnya tanggung jawab karyawan terhadap tugas yang diamanahkan kepadanya.

4. Tingkat kewaspadaan tinggi. Karyawan memiliki kewaspadaan tinggi akan selalu berhati-hati, penuh perhitungan dan ketelitian dalam bekerja, serta selalu menggunakan sesuatu secara efektif dan efisien.

5. Bekerja etis. Beberapa karyawan mungkin melakukan tindakan yang tidak sopan ke pelanggan atau terlibat dalam tindakan yang tidak pantas. Hal ini merupakan salah satu bentuk tindakan indisipliner, sehingga bekerja etis sebagai salah satu wujud dari disiplin kerja karyawan.

Menurut Soejono (2011:11), disiplin kerja dipengaruhi oleh faktor yang sekaligus sebagai indikator dari disiplin kerja, yaitu:

1. Ketepatan waktu.

2. Menggunakan peralatan kantor dengan baik.

3. Tanggung jawab yang tinggi.

4. Ketaatan terhadap aturan kantor.

5. Pegawai memakai seragam kantor.

\section{Pengertian Kinerja}

Kinerja dalam organisasi merupakan suatu jawaban berhasil atau tidaknya tujuan organisasi yang telah ditetapkan. "Kinerja adalah hasil

kerja secara kualitas dan kuantitas yang dicapai oleh seseorang pegawai dalam melaksanakan tugasnya sesuai dengan tanggung jawab yang diberikan kepadanya" (Mangkunegara, 2009:67). "Kinerja merupakan hasil atau tingkat keberhasilan seseorang atau keseluruhan selama periode tertentu di dalam melaksanakan tugas dibandingkan dengan berbagai kemungkinan, seperti standar hasil kerja, target atau sasaran atau kriteria yang telah ditentukan terlebih dahulu dan telah disepakati bersama" (Rivai dan Basri dalam Sinambela, 2012:6).

\section{Faktor- mempengaruhi Kinerja}

Menurut Wirawan (2009:6-8), kinerja pegawai merupakan hasil sinergi dari sejumlah faktor. Faktorfaktor tersebut yaitu:

1. Faktor internal pegawai, yaitu faktor-faktor dari dalam diri pegawai yang merupakan faktor bawaan dari lahir dan faktor yang diperoleh ketika ia berkembang. Faktor-faktor bawaan, misalnya bakat, sifat pribadi, serta keadaan fisik, dan kejiwaan.

2. Faktor-faktor lingkungan internal organisasi. Dalam melaksanakan tugasnya, pegawai memerlukan dukungan organisasi tempat ia bekerja. Dukungan tersebut sangat mempengaruhi tinggi rendahnya kinerja pegawai. Sebaliknya, jika sistem kompensasi dan iklim kerja organisasi buruk, kinerja karyawan akan menurun.

3. Faktor lingkungan eksternal organisasi. Faktor-faktor eksternal organisasi adalah keadaan, kejadian, atau situasi yang terjadi di lingkungan 
eksternal organisasi yang mempengaruhi kinerja karyawan. Selain itu budaya masyarakat juga merupakan faktor eksternal yang mempengaruhi kinerja karyawan.

\section{Manfaat Penilaian Kinerja}

"Penilaian kinerja memainkan peran penting dalam proses manajemen kinerja secara keseluruhan. Penilaian kinerja adalah proses yang digunakan organisasi untuk menilai kinerja karyawan" (Kaswan, 2012:213). Organisasi biasanya melakukan penilaian kinerja untuk berbagai tujuan, diantaranya:

1. Penilaian memberi justifikasi organisasi secara resmi untuk pengambilan keputusan pekerjaan.

2. Penilaian digunakan sebagai kriteria dalam validasi tes.

3. Penilaian memberi umpan balik kepada karyawan dan dengan demikian berfungsi sebagai sarana untuk pengembangan pribadi dan karir.

4. Penilaian dapat membantu mengidentifikasi kebutuhan pengembangan karyawan dan juga unutk meneguhkan tujuantujuan untuk program pelatihan.

5. Penilaian dapat mendiagnosis masalah-masalah organisasi dengan mengidentifikasi kebutuhan pelatihan dan karakteristik-karakteristik pribadi untuk dipertimbangkan dalam memperkerjakan, dan penilaian juga menyediakan landasan untuk membedakan antara karyawan yang berkinerja efektif dengan yang berkinerja tidak efektif.

6. Penilaian bersifat memotivasi, yaitu mendorong inisiatif, mengembangkan rasa tanggung jawab, dan merangsang usahausaha untuk berkinerja lebih baik.

7. Penilaian merupakan wahana komunikasi, sebagai dasar diskusi tentang hal-hal yang berhubungan dengan pekerjaan antara atasan dan bawahan, kedua pihak dapat mengenal lebih baik.

8. Penilaian dapat berfungsi sebagai dasar untuk perencanaan sumber daya manusia dan pekerjaan, yaitu memberikan input yang berharga untuk inventarisasi keterampilan dan perencanaan sumber daya manusia.

9. Penilaian dapat dijadikan dasar penilaian manajemen sumber daya manusia yaitu untuk menentukan apakah program manajemen sumber daya manusia sudah ada efektif.

\section{Indikator Kinerja}

John Miner dalam Sudarmanto (2009:11), mengemukakan 4 (empat) indikator yang dapat digunakan untuk mengukur kinerja pegawai meliputi:

1. Kualitas, yaitu tingkat kesalahan, kerusakan, kecermatan.

2. Kuantitas, yaitu jumlah pekerjaan yang dihasilkan.

3. Penggunaan waktu dalam kerja yaitu tingkat ketidakhadiran, keterlambatan waktu.

4. Kerjasama dengan orang lain dalam bekerja.

\section{Kerangka Pemikiran}

"Kerangka berpikir merupakan model tentang bagaimana teori berhubungan dengan berbagai faktor yang telah diindentifikasi sebagaimasalah yang penting" (Sugiyono, 2010:88). 
Dari hasil uraian teoritis diatas ini digambarkan sebagai berikut: kerangka berpikir dalam penelitian

Gambar 1. Kerangka Berpikir

Sumber: Olahan Penulis 2019

METODE PENELITIAN

\section{Lokasi dan Waktu Penelitian}

Dalam rangka penulis proposal penelitian ini penulis mengambil lokasi penelitian pada Kantor Dinas Ketenagakerjaan Kota Medan yang berlokasi dijalan KH.Wahid Hasyim No. 14, Merdeka, Medan-Sumatera Utara dengan waktu penelitian Mei sampai Agustus 2019

\section{Populasi dan Sampel}

Populasi

"Populasi adalah wilayah generalisasi yang terdiri dari objek/subjek yang mempunyai kuantitas dari karakteristik tertentu yang ditetapkan oleh peneliti untuk dipelajari dan kemudian ditarik kesimpulan" Sugiyono (2014:148). Berdasarkan dari pendapat di atas, maka yang menjadi populasi dalam penelitian ini adalah pegawai Dinas Ketenagakerjaan Kota Medan yang berjumlah 30 (tiga puluh) orang.

\section{Metode Analisis Data}

Analisis Deskriptif

Analisis ini digunakan untuk mengetahui seberapa besar pengaruh fasilitas kantor, disiplin kerja terhadap kinerja pegawai Dinas Ketenagakerjaan Kota Medan. "Statistik deskriptif adalah statistik yang digunakan untuk menganalisis dengan cara mendeskripsikan atau menggambarkan data yang telah terkumpul sebagaimana adanya tanpa bermaksud membuat kesimpulan yang berlaku untuk umum atau generalisasi" (Sugiyono, 2010:207208).

Analisis Regresi Linier Berganda

"Pengujian hipotesis yang dilakukan dalam penelitian ini dilakukan dengan metode regresi linier yang digunakan untuk memprediksi seberapa jauh perubahan nilai variabel dependen, bila variabel independent dimanipulasi atau diubah-ubah atau dinaik turunkan" (Sugiono, 2010:206).

Rumus linier berganda:

$\mathrm{Y}=\mathrm{a}+\mathrm{b}_{1} \mathrm{X}_{1}+\mathrm{b}_{2} \mathrm{X}_{2}+\mathrm{e}$

Keterangan:

$\begin{array}{ll}\mathrm{Y} & =\text { Kinerja } \\ \mathrm{a} & =\text { Konstanta } \\ \mathrm{b}_{1}-\mathrm{b}_{2} & =\text { Koefisien Regresi } \\ \mathrm{X}_{1} & =\text { FasilitasKantor } \\ \mathrm{X}_{2} & =\text { Disiplin } \\ \mathrm{e} & =\text { eror }\end{array}$

\section{Uji Hipotesis}

Pengujian hipotesis digunakan untuk membuktikan atau memperjelas dari tujuan semula yaitu apakah ada pengaruh antara variabel bebas terhadap variabel terikat. Pengujian hipotesis penelitian dilakukan 
dengan pengujian secara simultan dan parsial.

\section{Uji Instrumen Penelitian}

1. Uji Validitas

2. Uji Realibilitas

Uji Asumsi Klasik

a. Uji Normalitas

b. Uji Multikolinierlitas

c. Uji Heterokedastisitas

Uji Parsial (Uji t)
Uji t (t-test) melakukan pengujian terhadap koefisien regresi secara parsial, pengujian ini dilakukan untuk mengetahui signifikansi peran secara parsial antara variabel independen terhadap variabel dependen dengan mengasumsikan bahwa variabel independen lain dianggap konstan.

$$
t=\frac{r \sqrt{n-2}}{\sqrt{1-R^{2}}}
$$

Keterangan:

$\mathrm{t}=$ Distribusi $\mathrm{t}$

$r=$ Koefisien korelasi parsial

$r^{2}=$ Koefisien determinasi

$\mathrm{n}=$ jumlah data

(t-test) hasil perhitungan ini selanjutnya dibandingkan dengan $\mathrm{t}$ tabel dengan menggunakan tingkat keyakinan 0,05. Kriteria yang digunakan adalah sebagai berikut:

diterima jika nilai $t_{\text {hitung }} \leq$ $t_{\text {tabel }}$ atau nilai sig $>\alpha$

ditolak jika nilai $t_{\text {hitung }} \geq t_{\text {tabel }}$ atau nilai $\operatorname{sig}<\alpha$

Bila terjadi penerimaan Ho maka dapat disimpulkan bahwa tidak terdapat pengaruh signifikan, sedangkan bila Ho ditolak artinya terdapat pengaruh yang signifikan.

Ho: $\beta=0$ : tidak terdapat pengaruh yang signifikan

Ha $: \beta \neq 0$ : terdapat pengaruh yang signifikan.

\section{Uji Simultan ( Uji F)}

Uji $F$ adalah pengujian terhadap koefisien regresi secara simultan. Pengujian ini dilakukan untuk mengetahui pengaruh semua variabel independen yang terdapat di dalam model secara bersama-sama (simultan) terhadap variabel dependen.

$$
\mathrm{F}=\frac{R^{2} / k}{\left(1-R^{2}\right) /(n-k-1)}
$$

Keterangan:

R2 = Koefisien determinasi

$\mathrm{k}=$ Jumlah variabel independen

$\mathrm{n}=$ Jumlah anggota data atau kasus

$\mathrm{F}$ hasil perhitungan ini dibandingkan dengan yang diperoleh dengan menggunakan tingkat resiko atau signifikan level $5 \%$ atau dengan degree freedom $=\mathrm{k}(\mathrm{n}-\mathrm{k}-1)$ dengan kriterian sebagai berikut: ditolak jika $F_{\text {hitung }}>$

$F_{\text {tabel }}$ atau nilai sig $<\alpha$ diterima jika $F_{\text {hitung }}<$ $F_{\text {tabel }}$ atau nilai sig $>\alpha$

Jika terjadi penerimaan $\mathrm{H}_{0}$, maka dapat diartikan tidak berpengaruh 
signifikan model regresi berganda yang diperoleh sehingga mengakibatkan tidak signifikan pula pengaruh dari variabel-variabel bebas bebas secara simultan terhadap variabel terikat.

Adapun yang menjadi hipotesis nol dalam penelitian ini adalah sebagai berikut:

$\mathrm{H}_{0}: \beta 1=\beta 2=\beta 3=0$ : tidak berpengaruh signifikan

Ha: $\beta 1 \neq \beta 2 \neq \beta 3 \neq 0$ : terdapat pengaruh yang signifikan

Pegujian hipotesis akan dilakukan dengan menggunakan tingkat signifikansi sebesar $0,05(\alpha=0)$ atau tingkat keyakinan sebesar 0,95. Dalam ilmu-ilmu sosial tingkat

$$
K d=r 2 \times 100 \%
$$

Dimana:

$K d=$ Koefisien determinasi

$r 2=$ Koefisien korelasi

Kriteria untuk analisis koefisien determinasi adalah:

a. Jika $K d$ mendeteksi nol (0), maka pengaruh variabel independent terhadap variabel dependent lemah.

b. Jika $K d$ mendeteksi satu (1), maka pengaruh variabel independent terhadap variabel dependent kuat. signifikansi $\quad 0,05 \quad$ sudah lazim digunakan karena dianggap cukup tepat untuk mewakili hubungan antar-variabel yang diteliti.

\section{Uji Koefisien Determinan $\left(R^{\mathbf{2}}\right)$}

Koefisien determinasi merupakan ukuran untuk mengetahui kesesuaian atau ketepatan antara nilai dugaan atau garis regresi dengan data sampel. Apabila nilai koefisien korelasi sudah diketahui, maka untuk mendapatkan koefisien determinasi dapat diperoleh dengan mengkuadratkannya. Besarnya koefisien determinasi dapat dihitung dengan menggunakan rumus sebagai berikut:

\section{Coefficients $^{\mathrm{a}}$}

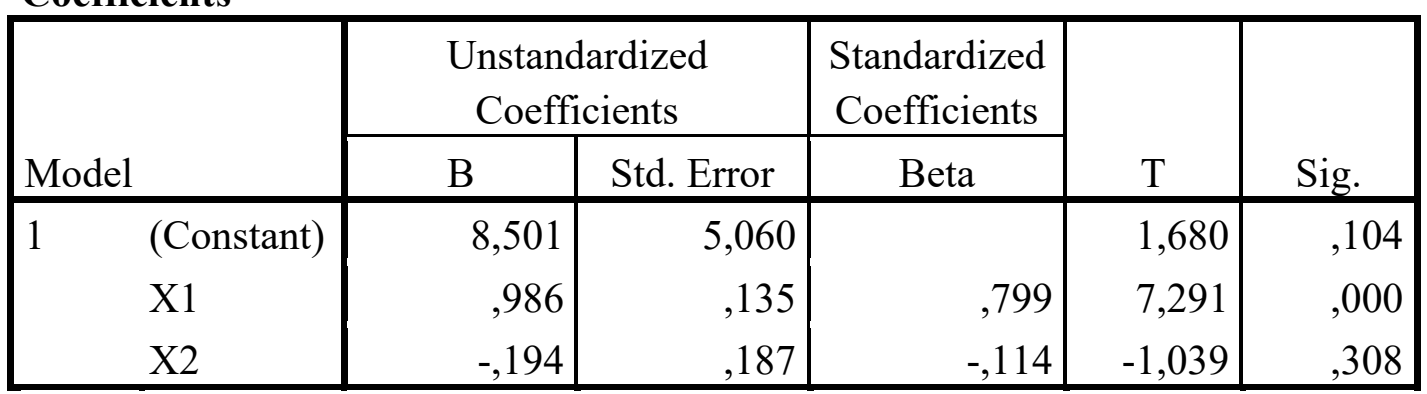

a. Dependent Variable: Y

Berdasarkan tabel di atas, persamaan regresi linier berganda dapat dilihat nilai konstanta ( nilai a) sebesar

\section{HASIL DAN PEMBAHASAN}

Uji Regresi Linier Berganda

Berdasarkan olahan data yang dilakukan, maka dapat diketahui bahwa model hubungan dari analisis regresi linier berganda ini dilihat dari tabel berikut: 
dapat diperoleh persamaan regresi, yaitu:

$$
\begin{array}{r}
\mathrm{Y}=8,501 \\
0,986 \mathrm{X}_{1}+0,194 \mathrm{X}_{2}
\end{array}+
$$

a. Dengan persamaan regresi linier tersebut dapat dijelaskan bahwa: Nilai konstanta sebesar 8,501 hal ini menyatakan bahwa tanpa adanya Fasilitas Kantor (X1) dan Kedisplinan Kerja (X2) maka perolehan Kinerja Pegawai (Y) adalah 8, 501.

b. Koefisien regresi untuk Fasilitas Kantor sebesar 0,986 hal ini menunjukkan bahwa setiap kenaikan $1 \%$ faktor Fasilitas
Kantor maka kinerja akan mengalami peningkatan sebesar 98, $6 \%$.

c. Koefisien regresi linier Kedisplinan Kerja sebesar 0,194 hal ini menunjukkan setiap kenaikan $1 \%$ faktor Kedisplinan Kerja maka kinerja akan mengalami penurunan sebesar 19,4\%.

\section{Uji Parsial ( Uji t)}

Uji $t$ ini dilakukan bertujuan untuk melihat tingkat signifikansi masingmasing variabel bebas terhadap variabel terikat.

\begin{tabular}{|c|c|c|c|c|c|c|}
\hline \multirow{2}{*}{\multicolumn{2}{|c|}{ Model }} & \multicolumn{2}{|c|}{$\begin{array}{c}\text { Unstandardized } \\
\text { Coefficients }\end{array}$} & \multirow{2}{*}{$\begin{array}{c}\text { Standardized } \\
\text { Coefficients }\end{array}$} & \multirow[b]{2}{*}{$\mathrm{T}$} & \multirow[b]{2}{*}{ Sig. } \\
\hline & & B & Std. Error & & & \\
\hline \multirow[t]{3}{*}{1} & (Constant) & 8,501 & 5,060 & & 1,680 & , 104 \\
\hline & $\mathrm{X} 1$ & ,986 &, 135 & ,799 & 7,291 &, 000 \\
\hline & $\mathrm{X} 2$ &,- 194 &, 187 &,- 114 & $-1,039$ & ,308 \\
\hline
\end{tabular}

Coefficients $^{\mathrm{a}}$

a. Dependent Variable: Y

Sumber: Hasil Pengolahan SPSS 22

$\begin{array}{llr}\text { Berdasarkan } & \text { pada } & \text { kriteria } \\ \text { pengambilan } & \text { keputusan } & \text { bahwa }\end{array}$ pengambilan keputusan bahwa signifikasi $<$ nilai alpha sebesar 0,05 maka hipotesis diterima dengan sebaiknya, apabila nilai signifikansi $>$ nilai alpha sebesar 0,05 maka hipotesis ditolak.

Tabel diatas menunjukan hasil uji $\mathrm{t}$ untuk variabel Fasilitas Kantor dengan nilai $t_{\text {hitung }}=7,291>t_{\text {tabel }}=$ 2,0518 dan diketahui nilai signifikansi dari Fasilitas Kantor adalah sebesar 0,000 dan nilai ini lebih kecil dari nilai alpha yang sebesar 0,05. Dengan demikian dinyatakan bahwa Fasilitas tidak memiliki pengaruh positif signifikansi terhadap kinerja para pegawai Dinas Ketenagakerjaan Kota Medan. Sedangkan Untuk hasil uji $\mathrm{t}$ variabel Kedisiplinan Kerja menunjukan nilai thitung $=1,039<$ $\mathrm{t}_{\text {tabel }}=2,0518$ dan diketahui nilai signifikansi dari Kedisiplinan Kerja adalah sebesar 0,308 dan nilai ini lebih besar dari nilai alpha 0,05. Dengan demikian dapat dinyatakan bahwa Kedisiplinan Kerja tidak memiliki pengaruh positif terhadap Kinerja para pegawai Dinas Ketenagakerjaan Kota Medan. Uji Simultan (Uji F)

Uji F dilakukan untuk mengetahui apakah variabel bebas secara 
bersama-sama berpengaruh secara

signifikan terhadap variabel terikat

ANOVA ${ }^{\mathrm{a}}$

\begin{tabular}{|c|c|c|c|c|c|c|}
\hline \multicolumn{2}{|c|}{ Model } & $\begin{array}{l}\text { Sum of } \\
\text { Squares }\end{array}$ & df & Mean Square & $\mathrm{F}$ & Sig. \\
\hline \multirow[t]{3}{*}{1} & Regression & 179,643 & 2 & 89,821 & 32,097 &, $000^{\mathrm{b}}$ \\
\hline & Residual & 75,557 & 27 & 2,798 & & \\
\hline & Total & 255,200 & 29 & & & \\
\hline
\end{tabular}

a. Dependent Variable: kinerja pegawai (Y)

b. Predictors: (Constant), kedisiplinan kerja (X2), fasilitas kantor (X1)

Berdasarkan tabel diatas dapat dilihat bahwa F Fitung sebesar 32,097 sedangkan besarnya $F_{\text {tabel }}$ yaitu $\mathrm{df}_{1}=$ $(\mathrm{k}-1)=(3-1=2) ; \mathrm{df}_{2}=(\mathrm{n}-\mathrm{k})=(30-$ $3=27)$, maka diperoleh $F_{\text {tabel }}$ sebesar 3,35 dapat diliha bahawa nilai $F_{\text {hitung }}$ lebih besar dari $\mathrm{F}_{\text {tabel }}(32,097>3,35)$ dengan signifikasi $0,000<\alpha=0.05$. Dapat disimpulkan bahwa ada pengaruh Fasilitas Kantor dan
Kedisiplinan Kerja secara simultan (bersamaan) terhadap Kinerja para pegawai Dinas Ketenagakerjaan Kota Medan.

\section{Uji Koefisien Determinasi $\left(\mathbf{R}^{\mathbf{2}}\right)$}

Untuk dapat mengetahui besarnya

Fasilitas Kantor dan Kedisiplinan

Kerja dalam menjelaskan Kinerja

Pegawai dapat dilihat pada koefisien determinasinya yang berbeda .

Model Summary

\begin{tabular}{|l|c|r|r|r|}
\hline Model & R & R Square & $\begin{array}{c}\text { Adjusted R } \\
\text { Square }\end{array}$ & $\begin{array}{c}\text { Std. Error of } \\
\text { the Estimate }\end{array}$ \\
\hline 1 &, $839^{\mathrm{a}}$ &, 704 &, 682 & 1,673 \\
\hline
\end{tabular}

a. Predictors: (Constant), X2, X1

b. Dependent Variable: Y

Sumber: hasil Pengolahan SPSS 22

Berdasarkan pada tabel diatas diketahui bahwa nilai Adjuted $R$ Square adalah sebesar 0,682 artinya bahwa Fasilitas Kantor dan Kedisiplinan Kerja mampu menjelaskan Kinerja Pegawai adalah $68,2 \%$ dan sisanya $31,8 \%$, dijelaskan variabel lain yang yang tidak dibahas dalam penelitian ini.

\section{KESIMPULAN DAN SARAN Simpulan}

1. Berdasarkan pengujian hipotesis dengan uji $t$ diperoleh $t_{\text {hitung }}$ $(7,291)>t_{\text {tabel }}(2,0518)$ artinya fasilitas kantor berpengaruh signifikansi positif terhadap kinerja pegawai, dan berdasarkan pengujian hipotesis dengan uji $\mathrm{t}$ diperoleh $t_{\text {hitung }}(1,039)<t_{\text {tabel }}$ $(2,0518)$ artinya kedisiplinan kerja tidak berpengaruh signifikansi positif terhadap kinerja pegawai.

2. Dari hasil analisis yang telah dilakukan diperoleh analisis regresi linier berganda yaitu: $\mathrm{Y}=$ $8,501+0,986 \mathrm{X}_{1}+0,194 \mathrm{X}_{2}$ yang berarti konstanta sebesar 8,501 
dapat diartikkan bahwa kinerja pegawai (Y) akan bernilai sebesar 8,501 jika fasilitas kantor X1 bernilai nol (tidak ada. Koefisien regresi Linier berganda (X1) sebesar 0,986 menyatakan jika pelatihan semakin tinggi maka kinerja pegawai semakin meningkat sebaliknya dengan kedisiplinan kerja X2 yang mana koefisien linier berganda (X2) sebesar 0,194 menyatakan jika kedisiplinan mengalami penurunan maka kinerja pegawai akan semakin menurun. Dan hasil Uji secara simultan (Uji F) bahwa nilai $F_{\text {hitung }} 32,097$ dengan tingkat signifikan 0,000 . Sedangkan nilai $\mathrm{F}_{\text {tabel }}$

3. 3,35 Nilai $F_{\text {hitung }}>F_{\text {tabel }}(32.097$ $>3,35)$ dan tingkat signifikansi $(0,000<0,05)$ dengan hipotesis $\mathrm{H}_{\mathrm{O}}$ ditolak dan $\mathrm{H}_{\mathrm{a}}$ diterima sehinggan menunjukkan bahwa Fasilitas Kantor dan Kedisiplinan Kerja secara bersama-sama berpengaruh positif dan signifikan terhadap Kinerja Pegawai.

4. Bedasarkan koefisien determinasi ( adjusted $\mathrm{R}$ squer) yang diperoleh sebesar 0,682 hal ini berarti kontribusi pengaruh fasilitas kantor dan kedisiplinan kerja adalah sebesar 68,2 \% terhadap kedisiplinan kerja sedangkan sisanya yaitu sebesar $31,8 \%$.

\section{Saran}

1. Variabel fasilitas kantor pada penelitian ini merupakan variabel dominan yang memengaruhi kinerja pegawai pada Dinas Ketenagakerjaan Kota Medan, diharapkan pada atasan untuk dapat memperhatikan kondisi lingkungan kerja yang mempunyai pengaruh positif terhadap kinerja pegawai dan memberikan arahan serta

2. Bimbingan kepada para pegawi terhadap kerja pegawai dan pengaturan tata letak dan kerapian ruangan serta susunan fasilitas kantor pada rungan pegawai.

3. Variabel kedisiplinan kerja memiliki pengaruh positif dan signifikan dalan meningkatkan kinerja para pegawai sehingga disarankan kepada pemimpin Dinas Ketenagakerjaan Kota Medan untuk memberikan penilain atas kinerja pegawai.

4. Penelitian ini menggunkan dua variabel bebas untuk mengukur kinerja pegawai, sehingga disarankan bagi peneliti selanjutnya diharapkan dapat memperhatikan variabel tersebut dengan mengembangkan indikator yang lebih tepat atau menambahkan variabel lainnya yang lebih relevan yang memiliki pengaruh terhadap kinerja pegawai sehingga dapat membantu tercapainya tujuan instansi/perusahaan pada Dinas Ketenagakerjaan Kota Medan.

\section{DAFTAR PUSTAKA}

Lupiyoadi. Handayani. 2006. Manajemen Pemasaran Jasa. Salemba Empat. Jakarta.

Faisal. 2005. Pengaruh Insentif dan Fasilitas Kerja terhadap Produktivitas Karyawan. Yogyakarta: FE-UGM.

Ghozali, Imam. 2011. Aplikasi Analisis Multivariate dengan Program SPSS. Semarang: 
Badan Penerbit Universitas Diponegoro.

Mathis, John. 2012. Manajemen Sumber Daya Manusia. Jakarta: PT Salemba Empat.

Mangkunegara, Anwar Prabu. 2009. Manajemen Sumber Daya Manusia Perusahaan. Bandung: PT. Remaja Rosda Kary

Sinambela, Lijan Poltak. 2012. Kinerja Pegawai Teori Pengukuran dan Implikasi. Yogyakarta: Graha Ilmu.

Soejono. 2011. Sistem dan Prosedur Kerja. Edisi Ke-5. Jakarta: Bumi Aksara.

Sudarmanto. 2009. Kinerja dan Pengembangan Kompetensi SDM. Yogyakarta: Pustaka Pelajar.

Sugiyono. 2014. Metode Penelitian Kuantitatif Kualitatif dan $R \& D$. Bandung: Alfabeta.

Veithzal, Rivai. 2010. Manajemen Sumber Daya manusia. Jakarta: Grafindo Persada.

Wirawan. 2009. Evaluasi Kenerja Sumber Daya Manusia Teori Aplikasi, dan Penelitian. Jakarta: Salemba Empat.

Sibagariang, O., Manalu, T., \& Girsang, W. (2019). PENGARUH PELATIHAN DAN DISIPLIN KERJA TERHADAP KINERJA KARYAWAN PADA PT. SANY TOGA GEMILANG. Jurnal Darma Agung, 27(2), 924-935.

doi:10.46930/ojsuda.v27i2.262
Gunawan, S., Tanuwijaya, N., Paulus, O., \& Linda, L. (2019). PENGARUH INSENTIF DAN KOMUNIKASI TERHADAP KINERJA KARYAWAN PADA PT ASIA KARET. Jurnal Darma Agung, 27(2), 10251039.

doi:10.46930/ojsuda.v27i2.235

Desani, A., Tangelica, M., \& Irisa, W. (2019). PENGARUH KOMUNIKASI DAN KOMITMEN TERHADAP KINERJA KARYAWAN PT. GARUDA MESIN AGRI. Jurnal Darma Agung, 27(2), 1063- 1071.

doi:10.46930/ojsuda.v27i2.274 